\title{
Physiological potential and health of soybean seeds obtained from organic and conventional systems ${ }^{1}$
}

\author{
Helio Fernandes Ibanhes Neto ${ }^{2 *}$, Gustavo Henrique Freiria ${ }^{2}$, Denis Santiago \\ da Costa $^{3}$, Cássio Egidio Cavenaghi Prete ${ }^{2}$ iD, Lúcia Sadayo Assari Takahashi ${ }^{2}$
}

\begin{abstract}
The quality of seeds produced is the result of the management practices used and environmental conditions during growing. The aim of this study was to evaluate the physiological potential and the health of soybean seeds produced in an organic and conventional system. The genotypes UEL 110 and 122 and BRS 257 and 284 were tested in organic and conventional systems in a randomized block design. The following characteristics were evaluated: moisture content; thousand seed weight (TSW); germination (G) and first count of germination (FCG); tetrazolium (TZ); classification, length, and dry matter of seedlings; and seed health. Analysis of variance was performed separately for the management systems, followed by combined analysis. When significant, the Tukey test $(\mathrm{p}<0.05)$ was applied. Multivariate analysis was performed using $\mathrm{R}$ software. There was not significance between genotypes and management systems. The conventional management system performed positively for the characteristics TSW, G, TZ, FCG, classification, and length and dry matter of seedling roots, as well as for plant health. The UEL genotypes obtained higher TSW; UEL 110, lower germination; and BRS 257, a smaller number of ungerminated seeds and higher infestation by Cladosporium spp. The seeds produced under the organic system have greater weight and lower infestation by contaminants, whereas the conventional system produces seeds of better physiological quality and lower contamination by Phomopsis and bacteria. The genotype BRS 257 may have seeds multiplied in the organic and conventional management systems.
\end{abstract}

Index terms: Glycine max, seed health, germination, vigor, seed pathology.

\section{Potencial fisiológico e sanidade de sementes de soja obtidas a partir de manejo orgânico e convencional}

\begin{abstract}
RESUMO - A qualidade da semente produzida é o reflexo do manejo empregado e das condições ambientais durante o cultivo. Objetivou-se avaliar o potencial fisiológico e a sanidade de sementes de soja produzidas em sistema orgânico e convencional. Foram testados os genótipos UEL 110 e 122, BRS 257 e 284, nos manejos orgânico e convencional em delineamento de blocos casualizados. Foram avaliados o teor de água, peso de mil sementes (PMS), germinação (G) e primeira contagem (PCG), tetrazólio (TZ), classificação, comprimento e massa seca de plântulas e sanidade. Realizou-se análise de variância separadamente para manejo, seguida da análise conjunta. Quando significativo aplicou-se teste de Tukey ( $<<0,05)$. Realizou-se análise multivariada, utilizando o software R. Não houve significância entre genótipos e sistemas de manejo. Para sistemas de manejo, o convencional se desempenhou positivamente para as características PMS, G, TZ, PCG, classificação, comprimento e massa seca de raiz das plântulas, além da sanidade. Os genótipos UEL obtiveram maior PMS, UEL 110 menor germinação, BRS 257 menor número de sementes não germinadas e maior infestação por Cladosporium spp. As sementes produzidas sob manejo orgânico apresentam maior peso e menor infestação por contaminantes, enquanto o manejo convencional produz sementes de melhor qualidade fisiológica e menor contaminação de Phomopsis e bactérias. O genótipo BRS 257 pode ter sementes multiplicadas nos manejos orgânico e convencional.
\end{abstract}

Termos para indexação: Glycine max, germinação, vigor, patologia de sementes.

\footnotetext{
${ }^{1}$ Submitted on 10/02/2018. Accepted for publication 03/01/2019.

${ }^{2}$ Departamento de Fitotecnia, Universidade Estadual de Londrina, Caixa Postal 10.011, 86057-970 - Londrina, PR, Brasil.
}

${ }^{3}$ IFMS, Campus de Nova Andradina, Caixa Postal 144, 79750-000 - Nova Andradina, MS, Brasil.

*Corresponding author <helioibanhes@hotmail.com> 


\section{Introduction}

Healthy foods, in the mind of a consumer, are those that throughout production take aspects of socioenvironmental responsibility and absence of chemical residues in the final product into consideration. Thus, among the various manners of meeting the needs of the consumer, crop management by means of organic agriculture has become prominent through ensuring lower use of rapid-release fertilizers and synthetic chemical products during growing (Assenheimer et al., 2009; Brighenti and Brighenti, 2009).

Soybean was introduced to Brazil at the end of the 1800s, and it gained prominence from the 1970s on when it came to be grown extensively in the Brazilian Cerrado (tropical savanna) region (Bonato, 1987). Currently, the grain is used for production of oils and meal for animal feed. However, due to changes in people's eating habits, the use of soybean has grown as an "in natura" food for human consumption, and interest in research has grown along with it (Oliveira et al., 2010).

By Brazilian law, to begin organic growing, seeds must be free of synthetic chemical and radioactive treatments, and they must meet standards of identity and quality for production and sale, in accordance with regulatory documents (Brasil, 2003a, 2003b, 2011). However, because of the requirements of many more laws and of the lack of studies, there is little availability of organic seeds, which creates considerable problems for the production process.

In seed technology, characteristics such as high physical and varietal purity, high germination and vigor values, and healthy seeds are desirable for high quality seed lots and are fundamental for ensuring agricultural production. These parameters are the result of management practices and conditions during their production, such as plant health treatments, climate conditions, and time and manner of harvest, processing, and storage (Kappes et al., 2009).

The advantages of quality seed lots are improved germination and emergence, establishment of rapid and uniform stand, higher yield, and less contamination of new areas by pests and plant pathogens (Minuzzi et al., 2010; Pádua et al., 2010). Within an organic production system, these characteristics can prevent or delay the occurrence of pests and diseases, and can lead to rapid closing of between-row areas, assisting in weed management. Kolchinski et al. (2005) found that the use high vigor seeds lead to a linear increase in leaf area index and dry matter production, and a $30 \%$ increase in final yield.

Transmission of plant pathogens from one area to another may occur due to their attachment to the seed coat or among seed tissues. Among the most important pathogens transmitted by soybean seed lots are Cercospora kikuchii, Colletotrichum truncatum, Fusarium spp., Macrophomina phaseolina,
Phomopsis sp., Rhizoctonia solani, Sclerotinia sclerotiorum, and Sclerotium rolfsii. Rainy conditions and high temperatures favor infection of seeds by fungi and are determining factors in a decline in physiological quality (Bernardi-Wenzel et al., 2006; Henning, 2015; Vasconcelos et al., 2008).

In organic systems, some technical studies can be highlighted for seed production seeking to meet legal requirements for production and studies related to germination and later performance.

Silva et al. (2012) found that there is no difference in seed vigor of coriander obtained from an organic management system and a conventional one. Casaroli et al. (2006) also obtained squash seeds with similar quality in the two management systems, and seeds obtained by management practices without the use of synthetic products were more contaminated by pathogens. Nogueira et al. (2017) obtained organic seeds of bell pepper without structural pruning and performed harvest at 51 days after anthesis.

It is noteworthy that Inagaki et al. (2018) concluded that production of organic soybean in the west of the state of Paraná was not viable, due to the difficulty of management, reduced number of studies, and low demand for organic foods by the population. Thus, the aim of this study was to investigate the physiological potential and health of soybean seeds produced in organic and conventional management systems.

\section{Materials and Methods}

The trial was conducted at the school-farm and at the plant science laboratory of the Universidade Estadual de Londrina (UEL) at $23^{\circ} 23^{\prime} \mathrm{S}$ and $51^{\circ} 11^{\prime} \mathrm{W}$ and 566 MASL. Climate was classified as type Cfa, according to Köppen. Before cultivation, for the purposes of characterization of the areas, soil samples were taken in the two areas used in the experiment, with the following results: area of conventional growing system $-\mathrm{P}=73.8 \mathrm{mg} \cdot \mathrm{dm}^{-3}, \mathrm{C}=$ $20.02 \mathrm{~g} . \mathrm{dm}^{-3}, \mathrm{pH}=5.0, \mathrm{Al}^{3+}=0.2 \mathrm{cmol} \cdot \mathrm{dm}^{-3}, \mathrm{H}^{+}+\mathrm{Al}^{3+}=$ $6.20 \mathrm{cmol}_{\mathrm{c}} \cdot \mathrm{dm}^{-3}, \mathrm{Ca}^{2+}=4.15 \mathrm{cmol} \cdot \mathrm{dm}^{-3}, \mathrm{Mg}^{2+}=0.98 \mathrm{cmol}$. $\mathrm{dm}^{-3}, \mathrm{~K}^{+}=0.61 \mathrm{cmol}_{\mathrm{c}} \cdot \mathrm{dm}^{-3}$, and $\mathrm{SB}=5.74 \mathrm{cmol}_{\mathrm{c}} \cdot \mathrm{dm}^{-3}$; and area of organic growing system $-\mathrm{P}=22.4 \mathrm{mg} \cdot \mathrm{dm}^{-3}, \mathrm{C}=$ 19.83 g. $\mathrm{dm}^{-3}, \mathrm{pH}=5.9, \mathrm{Al}^{3+}=0.0 \mathrm{cmol}_{\mathrm{c}} \cdot \mathrm{dm}^{-3}, \mathrm{H}^{+}+\mathrm{Al}^{3+}=$ $3.97 \mathrm{cmol}_{\mathrm{c}} \cdot \mathrm{dm}^{-3}, \mathrm{Ca}^{2+}=6.67 \mathrm{cmol}_{\mathrm{c}} \cdot \mathrm{dm}^{-3}, \mathrm{Mg}^{2+}=1.89 \mathrm{cmol}_{\mathrm{c}}$. $\mathrm{dm}^{-3}, \mathrm{~K}^{+}=0.59 \mathrm{cmol}_{\mathrm{c}} \cdot \mathrm{dm}^{-3}$, and $\mathrm{SB}=9.15 \mathrm{cmol}_{\mathrm{c}} \cdot \mathrm{dm}^{-3}$.

To carry out the trial, two experiments (conventional management system and organic management system) were set up in areas distant from each other in a randomized block experimental design for later performance of combined analysis. In each management system four soybean cultivars were used; three cultivars were classified as "food type" (UEL 110, UEL 122, 
and BRS 257), since they did not have lipoxygenase in their composition, and one as "common" type (BRS 284).

Seeds were sown mechanically on 04 Nov. 2016 for the two management systems. The plots were set up in four 5 -meter rows, spaced at $0.45 \mathrm{~m}$, with a density of 15 seeds per linear meter. The experimental areas were not irrigated.

The conventional management system was conducted in an area under the no-tillage system, with black oats in the previous crop season. To grow the crop, the area was desiccated seven days before sowing with the herbicide paraquat (Gramoxone ${ }^{\circledR}$ ) at the minimum recommended rate, 1.5 L.ha', and at sowing, $250 \mathrm{~kg} \cdot \mathrm{ha}^{-1}$ of the formulation 04-14-08 was used as base fertilization. The seeds of the cultivars tested were treated with the fungicide/insecticide mixture pyraclostrobin, thiophanate methyl, and fipronil (Standak Top ${ }^{\circledR}$ ) with $0.002 \mathrm{~L}^{\mathrm{kg}}{ }^{-1}$ and inoculated with Bradyrhizobium japonicum SEMIA 5079 and $5080\left(5 \times 10^{9}\right.$ colony forming units per $\mathrm{mL}$ ) at the rate of $100 \mathrm{~mL}$ per $50 \mathrm{~kg}$ of seeds. Weed control up to closing of the between-row area

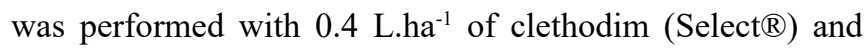
fomesafen + fluazifop-p-butyl (Fusiflex $\left.{ }^{\circledR}\right)$ at the commercial rate of 2 L.ha $^{-1}$. Pest control occurred in accordance with Embrapa (2010); whenever a control level was reached, the products teflubenzuron (Nomolt $\AA$ ) and flubendiamida (Belt $\left.{ }^{\circledR}\right)$ were used at the rates of $0.12 \mathrm{~L}^{2} \mathrm{ha}^{-1}$ and 0.012 kg.ha ${ }^{-1}$, respectively, for caterpillar control, while 0.8 L.ha $^{-1}$ of imidacloprid and beta-cyfluthrin (Connect $\AA$ ) was used for stink bug complex. Disease management occurred with two applications, for control of Asian soybean rust (causal agent Phakopsora pachyrhizi) using $0.4 \mathrm{~L}^{\mathrm{L}} \mathrm{ha}^{-1}$ of trifloxystrobin and prothioconazole $\left(\mathrm{Fox}^{\circledR}\right)$ at the beginning of flowering, and 0.3 L.ha ${ }^{-1}$ of azoxystrobin and cyproconazole (Priori Xtra ${ }^{\circledR}$ ) after the withdrawal period of 14 days from the first application.

For the organic management system, the area used was in fallow for four months and was prepared by mowing and disking for weed management before sowing. The seeds were inoculated only with the microorganisms used in the conventional treatment. Manual weeding was used during crop development until closing of the between-row area, which occurred at 42 days after sowing.

For entomological control, $0.02 \mathrm{~kg} \cdot \mathrm{ha}^{-1}$ of baculovirus was applied for control of velvetbean caterpillar (Anticarsia gemmatalis), while control of stink bug complex occurred through applications of neem (Azadirachta indica) oil at the rate

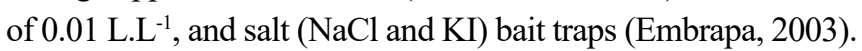
For control of plant pathogens, especially Asian rust, preventive applications were made of Bordeaux mixture (copper(II) sulfate, slaked lime, and water) in $5 \mathrm{~mL} . \mathrm{L}^{-1}$, from the time of closing of the between-row area until R5.3, whenever the weather forecasts were favorable to development of the disease.

During the crop period, weather data were monitored and recorded, as shown in Figure 1. Harvest was performed manually at the point of physiological maturity (R8), disregarding the outer rows and $0.5 \mathrm{~m}$ from the ends of the

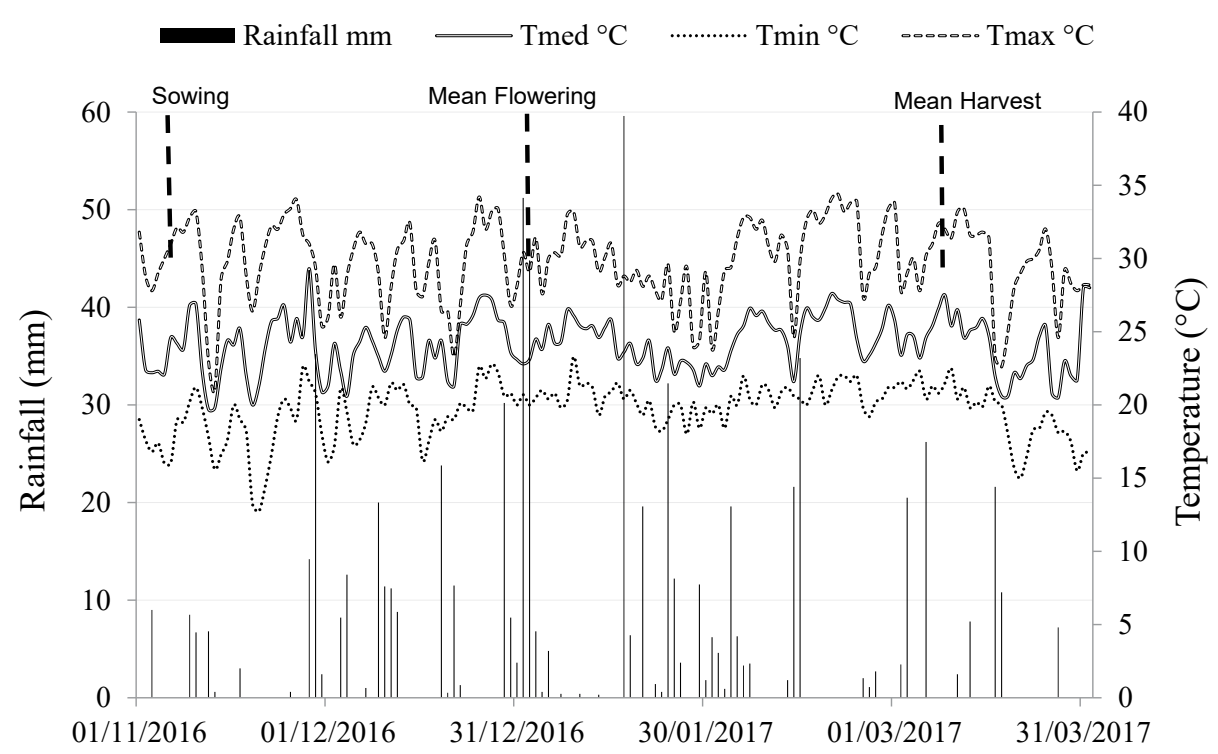

Source: Adapted from the Instituto Agronômico do Paraná (2016/2017) by the author.

Figure 1. Climate data of rainfall $(\mathrm{mm})$ and minimum, maximum, and mean temperatures $\left({ }^{\circ} \mathrm{C}\right)$ in reference to the growing period of the treatments in the experimental field. 
plots. The seeds were dried under laboratory conditions (mean temperature of $25^{\circ} \mathrm{C}$ ), manually processed, stored in paper bags, and kept in cold storage at $10^{\circ} \mathrm{C}$ and $45 \%$ moisture until the tests described below were performed.

Moisture content: this test was performed using the laboratory oven drying method (model 30 L, Nova Ética ${ }^{\circledR}$ ) at $105 \pm 3{ }^{\circ} \mathrm{C}$ in which two study samples of $4.5 \pm 0.5$ grams each were dried for 24 hours and then weighed again; the moisture percent in wet basis was determined by the difference between wet weight and dry weight (Brasil, 2009b).

Thousand seed weight (TSW): this test was performed by counting eight hundred seed subsamples and weighing them (analytical balance with $220 \mathrm{~g}$ capacity and precision of $0.0001 \mathrm{~g}$ ); the values of 1000 seed weight were adjusted to $13 \%$ moisture and expressed in grams (Brasil, 2009b).

Tetrazolium test (TZ): this test used two replications of 50 seeds per treatment, which were slowly pre-moistened with distilled water by rolling them in Germitest ${ }^{\circledR}$ paper and keeping them at $25{ }^{\circ} \mathrm{C}$ for 16 hours. After that, the seeds were placed in a $0.075 \%$ tetrazolium solution $(2,3,5$ triphenyltetrazolium chloride) at a temperature of $40^{\circ} \mathrm{C}$ for 180 minutes in an aging chamber. Interpretation followed recommendations for color, intensity, and position of the lesions, characterizing the seeds as viable or inviable, and the proportion of inviability by stink bug attack was indicated. These results were expressed in percentage (França-Neto et al., 1999).

Germination test $(G)$ : this test was performed through four replications of 50 seeds per treatment, which were arranged on two sheets of Germitest ${ }^{\circledR}$ paper and covered with a third sheet, all moistened with distilled water in the amount of 2.5 times the dry weight of the substrate, and kept in the form of a roll. The roll was maintained in a Mangelsdorf germinator at $25^{\circ} \mathrm{C}$, with evaluations at five days as first count and, finally, at eight days for the percentage of normal (NS) and abnormal (AS) seedlings (Brasil, 2009b). In addition, the seedlings were classified, separating the normal seedlings in relation to greater (Strong NS) and lesser (Weak NS) vigor, in accordance with Nakagawa (1999).

Length and dry matter of normal seedlings: this measure was obtained from four replications of 20 seeds and carried out in a manner similar to germination, however, with the micropyle positioned downward and placed in the upper third of the roll and without lighting. The samples were kept for seven days at $25{ }^{\circ} \mathrm{C}$ in a Mangelsdorf germinator sealed off from light, and evaluations were made through root length (RL) and shoot length (SL) of seedlings measured with a millimeter ruler (Nakagawa, 1999). After determination of length, dry matter was evaluated by placing normal seedlings in paper bags and maintaining them in an air circulation laboratory oven at $80{ }^{\circ} \mathrm{C}$ for 24 hours. The results of weighing were divided by the number of normal seedlings of the replications of length, and the results were expressed in milligrams per seedling (Nakagawa, 1999).

Seed pathology: the seed health was performed by incubation of the seeds in paper substrate (Blotter Test) with 16 replications of 25 seeds for each treatment (Brasil, 2009a). An optical microscope (CH30, Olympus $\left.{ }^{\circledR}\right)$ with 4-40X magnification was used in evaluation, checking for fructification of fungi and morphological analysis of the structures. Qualitative results were expressed in terms of genera found and quantitative results by the percentage of occurrence.

From the data obtained, analysis of normality and homogeneity of variance were made by the Shapiro Wilk test and Hartley test, respectively. When necessary, the percentage data were transformed by length and by weight. Based on individual analyses of variance, having obtained the residual mean squares for each management system, a proportion of $7: 1$ was found between them for carrying out combined analysis. When the source of variation was significant, the Tukey test at $5 \%$ probability of error was applied. Multivariate principal component analysis was applied for the purpose of verifying multiple interactions among the characteristics and treatments evaluated that were not indicated in the previous analysis. The statistical software $\mathrm{R}$ was used for all the tests.

\section{Results and Discussion}

The treatments sown all on the same date showed variations in the number of days to physiological maturity (R8) due to the cycle of each genotype. The mean values of the materials obtained from the organic management system were $120,119,116$, and 115 days for maturation of UEL 110, UEL 122, BRS 257, and BRS 284, respectively, whereas for the conventional management system, the mean values of $119,118,120$, and 114 days were obtained for maturation of UEL 110, UEL 122, BRS 257, and BRS 284, respectively.

After processing the lots and natural drying of the seeds, the moisture content was $8 \%$ (w.b.), indicating that all the treatments achieved a similar condition. The seeds were in storage conditions, i.e., with reduced metabolism, due to the moisture content adequate for maintaining the quality of the seed lots, thus reducing the interference of this factor on the changes in viability, vigor, and seed health.

Thousand seed weight (TSW) did not show statistical difference for interaction, but rather in an isolated manner for management systems and genotypes. In relation to management, there was greater TSW when the organic system was applied compared to the conventional system, whereas for the cultivars, 
the genotypes UEL 110 and UEL 122 stood out with greater weight in relation to BRS 257 and BRS 284 (Table 1).

For characteristics related to the physiological potential of seeds in the germination and tetrazolium tests, the interaction evaluated between genotypes and management systems was not significant. When observing only the management systems, statistical superiority of the conventional system was found in relation to the organic system for normal seedlings (NS) in the germination test and viability in the tetrazolium test. In addition, a greater number of abnormal seedlings (AS) and ungerminated seeds (US) were observed in the germination test for organic growing, indicating the lower physiological potential of the seeds under this type of management system (Table 1).

Thus, even though greater TSW was observed in the organic system, this was found not to have a direct effect on seed physiological potential, indicating that there is not a necessary positive correlation between thousand seed weight and physiological potential. Kolchinski et al. (2005) found that for soybean, there was no statistical difference in the TSW of plants coming from high or low vigor seeds, with a difference only in the number of pods per plant. Tavares et al. (2013) also concluded that more vigorous soybean seeds are not always heavier. They concluded this through crop growth from seeds with low and high vigor that were subjected to water deficit for the purpose of analyzing yield per area and physiological quality of seeds.

The genotypes exhibited different responses for normal seedlings. The highest mean was for the cultivar BRS 257 and the lowest for UEL 110; the others (UEL 122 and BRS 284) had intermediate values. In regard to ungerminated seeds, the seed lots of UEL 110 and BRS 284 had the highest values, confirming the low quality of the UEL 110 material and intermediate quality of the BRS 284 material (Table 1). These differences were attributed to peaks of rain and high temperatures near harvest time.

Castro et al. (2016) evaluated the occurrence of rains near harvest time and also found differences in physiological potential in post-harvest and after storage for different soybean cultivars,

Table 1. Thousand seed weight (TSW), normal seedlings (NS), abnormal seedlings (AS), ungerminated seeds (US), viable seeds in tetrazolium (VST), inviable seeds in tetrazolium (IVST), and stink bug damage in tetrazolium (SBDT) in soybean genotypes obtained from organic and conventional growing.

\begin{tabular}{|c|c|c|c|c|c|c|}
\hline \multirow{2}{*}{\multicolumn{2}{|c|}{ UEL 110}} & \multicolumn{4}{|c|}{ Genotype } & \multirow{2}{*}{ Mean } \\
\hline & & UEL 122 & BRS 257 & BRS 284 & UEL 110 & \\
\hline \multirow{3}{*}{$\mathrm{TSW}^{1}(\mathrm{~g})$} & Org. & 152 & 146 & 130 & 131 & $140 \mathrm{~A}$ \\
\hline & Conv. & 144 & 140 & 120 & 115 & $130 \mathrm{~B}$ \\
\hline & Mean & $148 \mathrm{a}$ & $143 \mathrm{a}$ & $125 \mathrm{~b}$ & $123 \mathrm{~b}$ & \\
\hline \multirow{3}{*}{ NS (\%) } & Org. & 27 & 46 & 65 & 45 & $46 \mathrm{~B}$ \\
\hline & Conv. & 67 & 81 & 91 & 58 & $74 \mathrm{~A}$ \\
\hline & Mean & $47 \mathrm{~b}$ & $63 \mathrm{ab}$ & $78 \mathrm{a}$ & $51 \mathrm{ab}$ & \\
\hline \multirow{3}{*}{ AS (\%) } & Org. & 30 & 23 & 23 & 29 & $26 \mathrm{~A}$ \\
\hline & Conv. & 19 & 14 & 7 & 21 & $15 \mathrm{~B}$ \\
\hline & Mean & 24 & 18 & 15 & 25 & \\
\hline \multirow{3}{*}{ US (\%) } & Org. & 43 & 32 & 13 & 26 & $28 \mathrm{~A}$ \\
\hline & Conv. & 14 & 6 & 2 & 22 & $11 \mathrm{~B}$ \\
\hline & Mean & $29 \mathrm{a}$ & $19 \mathrm{ab}$ & $7 \mathrm{~b}$ & $24 \mathrm{a}$ & \\
\hline \multirow{3}{*}{ VST (\%) } & Org. & 45 & 39 & 44 & 39 & $42 \mathrm{~B}$ \\
\hline & Conv. & 72 & 64 & 52 & 40 & $57 \mathrm{~A}$ \\
\hline & Mean & 59 & 52 & 48 & 40 & \\
\hline \multirow{3}{*}{ IVST (\%) } & Org. & 55 & 61 & 56 & 61 & $58 \mathrm{~A}$ \\
\hline & Conv. & 28 & 36 & 48 & 60 & $43 \mathrm{~B}$ \\
\hline & Mean & 42 & 49 & 52 & 61 & \\
\hline \multirow{3}{*}{ SBDT (\%) } & Org. & 16 & 16 & 17 & 11 & 15 \\
\hline & Conv. & 9 & 11 & 23 & 13 & 14 \\
\hline & Mean & 13 & 14 & 20 & 12 & \\
\hline
\end{tabular}

${ }^{1} \mathrm{CV}(\%): \mathrm{TSW}=5.73 ; \mathrm{NS}=19.44 ; \mathrm{AS}=29.37 ; \mathrm{US}=40.19 ; \mathrm{VST}=16.91 ; \mathrm{IVST}=16.5 ; \mathrm{SBDT}=37.40$. Means followed by the same uppercase letter in the column and lowercase letter in the row do not differ from each other by the $\mathrm{F}$ test and Tukey test at $5 \%$ significance, respectively. (Source: the author). 
an effect attributed to the difference in lignin in the seed coats, providing different levels of tolerance to moisture stress.

Although a significant difference was not found in stink bug damage in the tetrazolium test (SBDT) for genotypes and management systems (Table 1), one of the problems that can compromise the physiological potential of seeds is stink bug attack while still in the field during the reproductive period of soybean. These insects have potential to reduce the vigor or even bring about inviability of seeds due to their manner of feeding by inserting their oral sucking apparatus in different regions of the grain during its formation, and they may damage the embryo. In addition to the physical damage caused, the attack will result in lesions open to colonization of other microorganisms in the affected tissue, including possible transmission of toxins (Armas et al., 2017; Nunes and Souza, 2016; Pinto et al., 2009). This indicates that the differences found in the quality of the lots is not related to stink bug attack, but may be attributed to other factors, such as plant pathogens.

Vigor evaluated by performance characteristics of the seedlings (first count of germination (FCG); classification in strong and weak normal seedlings (NS); root (RL), shoot (SL), and total length (TL); and root dry matter (RDM)) was only affected by the management systems, with superiority of the conventional system, whereas shoot dry matter (SDM) and total dry matter (TDM) did not show differences (Table 2).

Seed performance in relation to vigor may be affected by several factors, such as genotype, management steps during production, edaphic and climatic conditions, and also plant health aspects. Thus, the organic management system showed problems in seed physiological potential (Table 1).

Due to the similarity of the edaphic and climatic conditions that occurred for both management systems, the superiority of the conventional system for physiological potential may be attributed to the use of synthetic chemical molecules with greater effectiveness for control of insects and plant pathogens. The organic system is based on plant health control using natural compounds without addition of artificial products for prevention or cure in the face of external and environmental factors (França-Neto et al., 2010; Luz et al., 2007).

In terms of seed health, high and significant infestation of Phomopsis sp. and bacteria was observed in seeds produced under organic management, and this may have been worsened by the lower potential for control that natural products had in relation to synthetic products since, in the conventional system, there was significantly greater infestation only for the contaminant fungi Rhizopus spp. and Cladosporium spp. In comparison of genotypes, the latter fungus showed greater contamination in the material BRS 257 in relation to UEL 110 and 122 (Table 3).

Some species of the genus Phomopsis sp., such as $P$.

Table 2. First count of germination (FCG), seedling classification [strong and weak normal seedlings (NS)], root length (RL), shoot length (SL), and total length (TL), root dry matter (RDM), shoot dry matter (SDM), and total dry matter (TDM) of soybean genotypes obtained from organic and conventional growing.

\begin{tabular}{|c|c|c|c|c|c|c|}
\hline & & \multicolumn{4}{|c|}{ Genotype } & \multirow{2}{*}{ Mean } \\
\hline & & UEL 110 & UEL 122 & BRS 257 & BRS 284 & \\
\hline \multirow{3}{*}{ FCG $(\%)$} & Org. & 39 & 45 & 68 & 52 & $51 \mathrm{~B}$ \\
\hline & Conv. & 68 & 79 & 87 & 56 & $72 \mathrm{~A}$ \\
\hline & Mean & 54 & 62 & 78 & 54 & \\
\hline \multirow{3}{*}{ Strong NS (\%) } & Org. & 18 & 38 & 33 & 27 & $29 \mathrm{~B}$ \\
\hline & Conv. & 45 & 56 & 43 & 45 & $47 \mathrm{~A}$ \\
\hline & Mean & 31 & 47 & 38 & 36 & \\
\hline \multirow{3}{*}{ Weak NS (\%) } & Org. & 82 & 62 & 67 & 73 & $71 \mathrm{~A}$ \\
\hline & Conv. & 55 & 44 & 57 & 55 & $53 \mathrm{~B}$ \\
\hline & Mean & 69 & 53 & 62 & 64 & \\
\hline \multirow{3}{*}{$\mathrm{RL}(\mathrm{mm})$} & Org. & 56.6 & 90.3 & 85.4 & 61.5 & $73.5 \mathrm{~B}$ \\
\hline & Conv. & 87.7 & 122.7 & 112.2 & 86.1 & $102.2 \mathrm{~A}$ \\
\hline & Mean & 72.1 & 106.5 & 98.8 & 73.8 & \\
\hline \multirow{3}{*}{ SL (mm) } & Org. & 38.1 & 58.2 & 67.8 & 55.1 & $54.8 \mathrm{~B}$ \\
\hline & Conv. & 68.1 & 96.8 & 87.7 & 70.6 & $80.8 \mathrm{~A}$ \\
\hline & Mean & 53.1 & 77.5 & 77.7 & 62.9 & \\
\hline
\end{tabular}


Table 2. Continuation.

\begin{tabular}{|c|c|c|c|c|c|c|}
\hline & & \multicolumn{4}{|c|}{ Genotype } & \multirow{2}{*}{ Mean } \\
\hline & & UEL 110 & UEL 122 & BRS 257 & BRS 284 & \\
\hline \multirow{3}{*}{$\mathrm{TL}(\mathrm{mm})$} & Org. & 94.7 & 148.5 & 153.2 & 116.6 & $128.2 \mathrm{~B}$ \\
\hline & Conv. & 155.8 & 219.5 & 199.9 & 156.7 & $183.0 \mathrm{~A}$ \\
\hline & Mean & 125.2 & 184.0 & 176.5 & 136.7 & \\
\hline \multirow{3}{*}{ RDM (mg) } & Org. & 5.5 & 6.7 & 5.8 & 4.7 & $5.7 \mathrm{~B}$ \\
\hline & Conv. & 6.0 & 6.4 & 5.7 & 6.7 & $6.2 \mathrm{~A}$ \\
\hline & Mean & 5.8 & 6.6 & 5.8 & 5.7 & \\
\hline \multirow{3}{*}{$\mathrm{SDM}^{\mathrm{ns}}(\mathrm{mg})$} & Org. & 122.9 & 110.1 & 112.8 & 93.2 & 109.75 \\
\hline & Conv. & 82.2 & 106.0 & 97.0 & 109.1 & 98.58 \\
\hline & Mean & 102.55 & 108.05 & 104.9 & 101.15 & \\
\hline \multirow{3}{*}{$\mathrm{TDM}^{\mathrm{ns}}(\mathrm{mg})$} & Org. & 128.4 & 116.8 & 118.6 & 97.9 & 115.4 \\
\hline & Conv. & 88.2 & 112.4 & 102.7 & 115.9 & 104.8 \\
\hline & Mean & 108.3 & 114.5 & 110.7 & 106.9 & \\
\hline
\end{tabular}

${ }^{1} \mathrm{CV}(\%)$ : FCG $=18.48 ;$ Strong NS $=30.57$; Weak NS = 12.38; RL = 16.61; SL = 16.81; TL = 16.32; RDM = 15.47; SDM = 17.83; TDM = 17.30. Means followed by the same uppercase letter in the column and lowercase letter in the row do not differ from each other by the F test and Tukey test at $5 \%$ significance, respectively. (Source: the author).

Table 3. Soybean seed health from organic and conventional growing.

\begin{tabular}{|c|c|c|c|c|c|c|}
\hline & & \multicolumn{4}{|c|}{ Genotype } & \multirow{2}{*}{ Mean } \\
\hline & & UEL 110 & UEL 122 & BRS 257 & BRS 284 & \\
\hline \multirow{3}{*}{ Cercospora kikuchii ${ }^{\text {ns }}(\%)$} & Org. & 10 & 30 & 27 & 18 & 21 \\
\hline & Conv. & 23 & 7 & 18 & 11 & 15 \\
\hline & Mean & 17 & 18 & 22 & 15 & \\
\hline \multirow{3}{*}{ Colletotrichum truncatum ${ }^{\mathrm{ns}}(\%)$} & Org. & 1 & 0 & 4 & 0 & 1 \\
\hline & Conv. & 0 & 0 & 1 & 0 & 0 \\
\hline & Mean & 0 & 0 & 2 & 0 & \\
\hline \multirow{3}{*}{ Fusarium spp. ${ }^{\text {ns }}(\%)$} & Org. & 11 & 15 & 11 & 20 & 14 \\
\hline & Conv. & 12 & 7 & 9 & 10 & 9 \\
\hline & Mean & 12 & 11 & 10 & 15 & \\
\hline \multirow{3}{*}{ Phomopsis sp. (\%) } & Org. & 23 & 3 & 5 & 6 & $9 \mathrm{~A}$ \\
\hline & Conv. & 3 & 3 & 3 & 7 & $4 \mathrm{~B}$ \\
\hline & Mean & 13 & 3 & 4 & 6 & \\
\hline \multirow{3}{*}{ Aspergillus spp. ${ }^{\mathrm{ns}}(\%)$} & Org. & 2 & 0 & 0 & 0 & 1 \\
\hline & Conv. & 1 & 4 & 1 & 0 & 1 \\
\hline & Mean & 2 & 2 & 0 & 0 & \\
\hline \multirow{3}{*}{ Cladosporium spp. (\%) } & Org. & 3 & 4 & 17 & 12 & $9 \mathrm{~B}$ \\
\hline & Conv. & 7 & 8 & 43 & 18 & $19 \mathrm{~A}$ \\
\hline & Mean & $5 \mathrm{~b}$ & $6 \mathrm{~b}$ & $30 \mathrm{a}$ & $15 \mathrm{ab}$ & \\
\hline \multirow{3}{*}{ Rhizopus spp. (\%) } & Org. & 32 & 31 & 33 & 23 & $29 \mathrm{~B}$ \\
\hline & Conv. & 51 & 72 & 26 & 41 & $47 \mathrm{~A}$ \\
\hline & Mean & 41 & 51 & 29 & 32 & \\
\hline
\end{tabular}


Table 3. Continuation

\begin{tabular}{|c|c|c|c|c|c|c|}
\hline & & \multicolumn{4}{|c|}{ Genotype } & \multirow{2}{*}{ Mean } \\
\hline & & UEL 110 & UEL 122 & BRS 257 & BRS 284 & \\
\hline \multirow{3}{*}{ Bacteria (\%) } & Org. & 17 & 18 & 5 & 22 & $15 \mathrm{~A}$ \\
\hline & Conv. & 2 & 1 & 2 & 15 & $5 \mathrm{~B}$ \\
\hline & Mean & 10 & 9 & 3 & 18 & \\
\hline
\end{tabular}

${ }^{1} \mathrm{CV}(\%)$ :Cercospora kikuchii $=34.91 ;$ Colletotrichum truncatum $=1.01 ;$ Fusarium spp. $=58.36 ;$ Phomopsis $\mathrm{sp} .=67.99 ;$ Aspergillus spp.$=1.01 ;$ Cladosporium spp. $=37.60 ;$ Rhizopus spp. $=27.26$; Bacteria $=48.62$. Means followed by the same uppercase letter in the column and lowercase letter in the row do not differ from each other by the F test and Tukey test at 5\% significance, respectively. (Source: the author).

sojae Lehman and P. phaseoli (Desm.) Sacc., are causal agents of pod and stem blight in soybean. These fungi occur throughout Brazil, with high occurrence in extensive rainy periods near harvest, which delays this step and subjects pods to alternating wet and dry periods. In addition to practices for prevention and control during the crop cycle, the use of healthy seeds with fungicide treatment is recommended. However, the lack of curative synthetic molecules in the organic management system makes disease control a complex problem (Ito, 2013).

Comparison of the percentage of contamination by bacteria in the two systems shows an increase in organic management. Though considered secondary diseases for soybean, bacterioses also compromise initial development in the field. Currently, the plant bacteria registered as compromising the crop are Pseudomonas savastanoi pv. glycinea (bacterial blight), Xanthomonas axonopodis pv. glycines (bacterial pustule), Pseudomonas syringae pv. tabaci (wildfire), and Curtobacterium flaccumfaciens pv. flaccumfaciens (bacterial tan spot) (Godoy et al., 2014).

To better understand seed response, the results of multivariate statistical analysis were observed, seeking explanation for the different levels of seed physiological potential.

The principal components explained $67.35 \%$ of the variances (Figure 2). The biplot indicates contributions of $51.03 \%$ for principal component 1 (PC1) and $16.32 \%$ for principal component 2 (PC2). For PC1 to the right, positive correlations were observed, discriminating all the genotypes of the conventional management system and organic BRS 257, whereas to the left were BRS 284, UEL 110, and UEL 122 , all organic. In relation to $\mathrm{PC} 2$, positive correlations above the axis represented conventional UEL 122 and BRS 284 and organic UEL 110, and below the axis, organic UEL 122, BRS
257, and BRS 284 were identified, as well as conventional UEL 110 and BRS 284.

Upon relating the two displays in Figure 2, by the perspective of $\mathrm{PC} 1$, which holds the greater explanation of the variances, all the characteristics of the physiological attributes, such as NS, Strong NS, VST, FCG, RL, SL, RDM, and SDM, as well as storage fungi (Aspergillus spp.) and contaminants (Cladosporium spp. and Rhizopus spp.) are to the right of PC1. These characteristics may be associated with organic BRS 257 and all the conventional genotypes analyzed, indicating that they exhibited greater physiological potential and lower contamination by plant pathogens, with the exception of BRS 257, which had high correlation with Cladosporium spp., confirming the significance of Table 3.

To the left of PC1 are TSW (which stood out statistically in the organic materials), characteristics of abnormal seedlings, ungerminated seeds, inviable seeds in tetrazolium, stink bug damage in tetrazolium, and weak normal seedlings, as well as the pathogens Fusarium spp., Phomopsis sp., and bacteria, with positive correlation between them and negative correlation for the rest of the characteristics of high performance. These characteristics were associated with the genotypes UEL 110, UEL 122, and BRS 284 obtained from the organic management system, which can be considered the reasons for the low performance of these seed lots (Figure 2).

This reinforces the hypothesis that soybean plant pathogens interact with the management systems and environmental conditions in a different way. Thus, in Principal Component Analysis, the lots UEL 110, UEL 122, and BRS 284 produced under an organic management system had impaired performance due to diseases, corroborating the data of Table 1. 

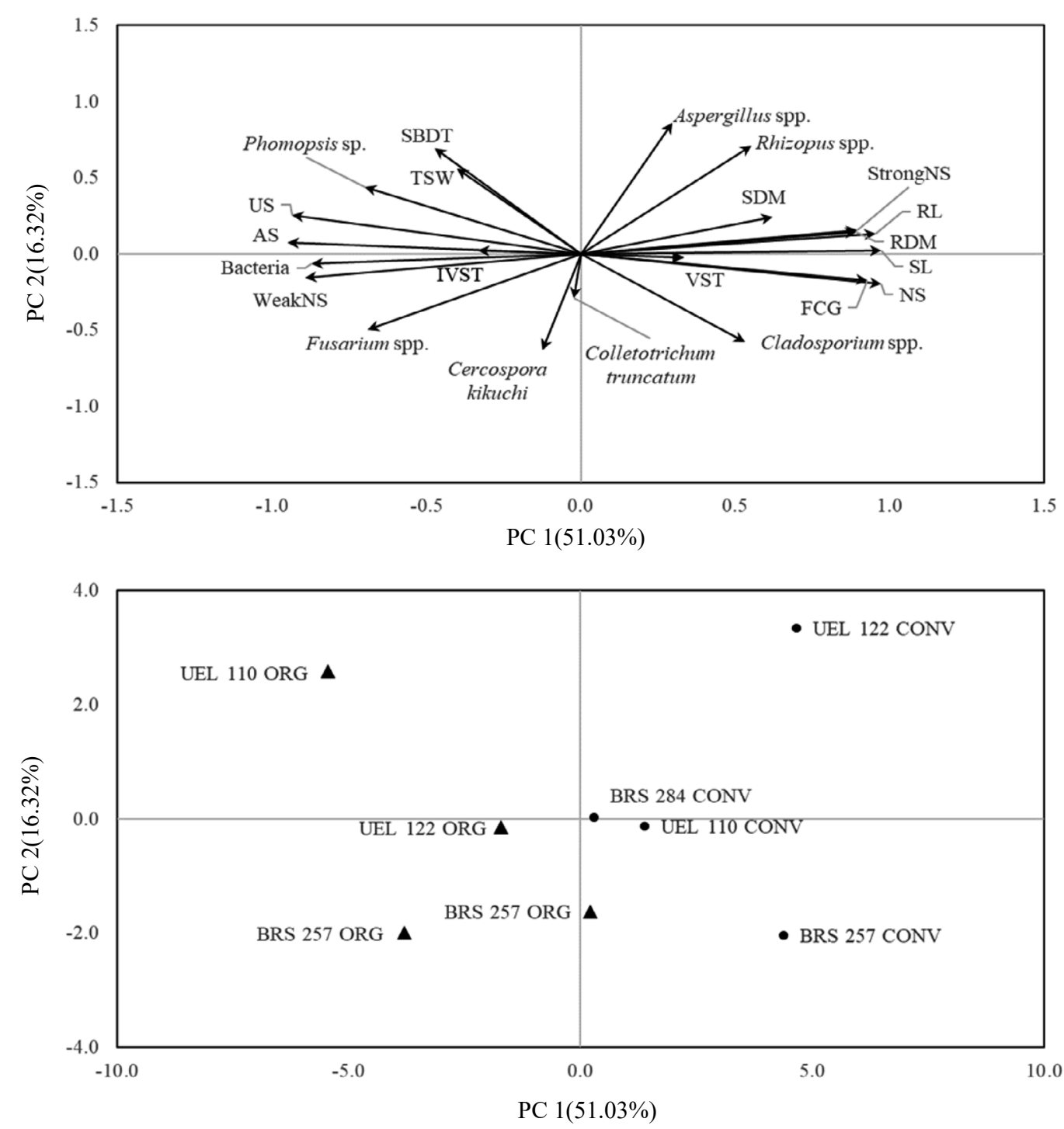

*ORG: organic, CONV: conventional. The characteristics of total length and total dry matter of seedlings were not included due to the root and shoot part already being registered in the analysis. (Source: the author).

Figure 2. Biplot indicating the variables projected by the first two principal components for discrimination of four soybean genotypes in two management systems.

\section{Conclusions}

There is the possibility of production of organic soybean seeds, just as of conventional system; nevertheless, new studies and practices must be developed to lead to better final physiological quality.

Greater thousand seed weight and lower infestation of contaminating pathogens is obtained from the organic management system, whereas the conventional system exhibits greater germination and vigor, with reduced contamination from Phomopsis sp. and bacteria.

The genotype BRS 257 has better performance under the organic system and similarity with other cultivars under the conventional management system, and it shows potential for both crop modalities.

\section{References}

ARMAS, F.S.; RAKES M.; PASINI, R.A.; PAZINI, BUENO, F.A.; ZANTEDESCHI, R.; GRÜTZMACHER, A.D.. Toxicidade de diferentes concentrações de calda sulfocálcica utilizada em cultivos orgânicos de soja sobre o parasitoide Telenomus podisi. Revista da Jornada da Pós-Graduação e Pesquisa - CONGREGA, v.14, 2017. http://trabalhos.congrega.urcamp.edu.br/index.php/14jpgp/article/ viewFile/2330/1398 
ASSENHEIMER, A.; CAMPOS, A. T.; GONÇALVES JÚNIOR, A. C. Análise energética de sistemas de produção de soja convencional e orgânica. Ambiência, v.5, n.3, p.443-455, 2009. https://revistas. unicentro.br/index.php/ambiencia/article/view/506/668

BERNARDI-WENZEL，J.; SIQUEIRA，A.L.; BURIN, F.A.G.; HEIN, D.P.R.; SILVEIRA, J.A.; ROMANI, S. Isolamento e atividade antagonística de fungos endofíticos de soja (Glycine max (L.) Merrill). SaBios-Revista de Saúde e Biologia, v.7, n.3, 2006. http://revista. grupointegrado.br/revista/index.php/sabios2/article/view/1343/467

BRASIL. Lei 10.831, de 23 dezembro de 2003. Diário Oficial da União, Brasil, 2003a.

BRASIL. Lei 10.711, de 5 de agosto de 2003. Diário Oficial da União, Brasil, 2003b.

BRASIL. Instrução Normativa 38. Diário Oficial da União, Brasil, 2011.

BRASIL. Manual de Análise Sanitária de Sementes / Ministério da Agricultura, Pecuária e Abastecimento. Secretaria de Defesa Agropecuária. Brasília: MAPA/ACS, 2009a. 200p.

BRASIL. Ministério da Agricultura Pecuária e Abastecimento. Regras para Análise de Sementes. Ministério da Agricultura Pecuária e Abastecimento. Secretaria de Defesa Agropecuária, Brasília: MAPA/ACS, 2009b. 399p.

BRIGHENTI, A.M.; BRIGHENTI, D.M. Controle de plantas daninhas em cultivos orgânicos de soja por meio de descarga elétrica. Ciência Rural, v.39, n.8, p.2315-2319, 2009. http://submission. scielo.br/index.php/cr/article/viewFile/1559/1305

BONATO, E.R. A soja no Brasil: história e estatística. Londrina: EMBRAPA, 1987.

CASAROLI, D.; GARCIA, D.C.; MUNIZ, M.F.B.; MENEZES, N.L. Qualidade sanitária e fisiológica de sementes de abóbora variedade Menina Brasileira. Fitopatologia Brasileira, Brasília, v. 31, n. 2, 2006. http://www.scielo.br/pdf/fb/v31n2/30009.pdf

CASTRO, E.M.; OLIVEIRA, J.A.; LIMA, A.E.; SANTOS, H.O.; BARBOSA, J.I.L. Physiological quality of soybean seeds produced under artificial rain in the pre-harvesting period. Journal of Seed Science, v.38, n.1, p.14-21, 2016. http://www.scielo.br/scielo. php?script $=$ sci_arttext\&pid=S2317-15372016000100014

EMBRAPA - Centro Nacional de Pesquisa de Soja. Soja orgânica: Alternativas para o manejo dos insetos-pragas. Londrina: Embrapa Soja, 2003. 83p. https://www.embrapa.br/soja/busca-depublicacoes/-/publicacao/463696/soja-organica-alternativas-para-omanejo-dos-insetos-pragas

EMBRAPA - Centro Nacional de Pesquisa de Soja. Tecnologias de produção de soja: região central do Brasil 2009 e 2010. Londrina: Embrapa Soja, 2010. 247p. https://www.embrapa.br/busca-depublicacoes/-/publicacao/242861/tecnologias-de-producao-de-soja--regiao-central-do-brasil-2009-e-2010

FRANÇA-NETO, J.B.; KRZYZANOWSKI, F.C.; COSTA, N.P. Metodologia do teste de tetrazólio em sementes de soja. In: KRZYZANOWSKI, F.C.; FRANÇA NETO J.B.; VIEIRA, D.V. (Ed.). Vigor de sementes: conceitos e testes. Londrina: ABRATES, 1999. p.8.5 - 8.5-28.
FRANÇA-NETO, J.B.; KRZYZANOWSKI, F.C.; HENNING, A.A.; PÁDUA, G.P. Tecnologia de produção de soja de alta qualidade. Informativo ABRATES, v.20, n.3, p.26-32, 2010. http://ainfo.cnptia. embrapa.br/digital/bitstream/item/30670/1/minicurso01.pdf

GODOY,C.V.;ALMEIDA,A.M.R.; SOARES, R.M.; SEIXAS, C.D.S.; DIAS, W.P.; MEYER, M.C.; COSTAMILAN, L.M.; HENNING, A.A. Doenças da soja (Glycine max (L.) Merrill). Sociedade Brasileira de Fitopatologia (SBF), p.1-32, 2014. https://ainfo.cnptia.embrapa.br/ digital/bitstream/item/125697/1/DoencasdaSoja.pdf

HENNING, A.A. Guia prático para identificação de fungos mais frequentes em sementes de soja. Brasília: Embrapa, 2015. 33p.

INAGAKI, M.N.; JUNQUEIRA, C.P.; BELLON, P.P. Desafios da produção de soja orgânica como determinante à implantação de seu cultivo para fins comerciais na região oeste do Paraná. Revista Gestão \& Sustentabilidade Ambiental, v.7, n.1, p.682-699, 2018. http:// www.portaldeperiodicos.unisul.br/index.php/gestao_ambiental/ article/view/5970

ITO, M.F. Principais doenças da cultura da soja e manejo integrado. Nucleus, v.3, n.3, p.83-101, 2013. http://www.nucleus.feituverava. com.br/index.php/nucleus/article/view/908/1041

KAPPES, C.; CARVALHO, M.A.C.; YAMASHITA, O. M. Potencial fisiológico de sementes de soja dessecadas com diquat e paraquat. Scientia Agraria, v.10, n.1, p.001-006, 2009. https://dialnet.unirioja. es/servlet/articulo?codigo $=2900637$

KOLCHINSKI, E.M.; SCHUCH, L.O.B.; PESKE, S.T. Vigor de sementes e competição intra-específica em soja. Ciência Rural, v.35, n.6, p.1248-1256, 2005. http://www.scielo.br/scielo.php?script=sci_ arttext\&pid=S0103-84782005000600004

LUZ, J.M.Q.; SHINZATO, A.V.; SILVA, M.A.D. Comparação dos sistemas de produção de tomate convencional e orgânico em cultivo protegido. Bioscience Journal, v.23, n.2, p.7-15, 2007. http://www.seer.ufu.br/index.php/biosciencejournal/article/ download/6842/4531

MINUZZI, A.; BRACCINI, A.L.; RANGEL, M.A.S.; SCAPIM, C.A.; BARBOZA, M.C.; ALBRECHT, L.P. Qualidade de sementes de quatro cultivares de soja, colhidas em dois locais no estado do Mato Grosso do Sul. Revista Brasileira de Sementes, v.32, n.1, p.176-185, 2010. http://www.scielo.br/pdf/rbs/v32n1/v32n1a20.pdf

NAKAGAWA, J. Testes de vigor baseados no desempenho das plântulas. In: KRZYZANOSKI, F.C.; VIEIRA, R.D.; FRANÇANETO, J.B. (Eds.). Vigor de sementes: conceitos e testes. Londrina, ABRATES, 1999. p.2.1-2.24.

NOGUEIRA, J.L.; SILVA, B.A.; MÓGOR, A.F.; GRZYBOWSKI, C.R.S.; PANOBIANCO, M. Quality of organically produced bell pepper seeds. Journal of Seed Science, v.39, n.2, p.100-105, 2017. http://dx.doi.org/10.1590/2317-1545v39n2159173

NUNES, C.D.; SOUZA, R.C.T. Metodologia para identificação do percevejo marrom na lavoura de soja com base em visão computacional e aprendizagem de máquina. FCV Empresarial, v.8, p.10-14, 2016. https://revista.fcv.edu.br/index.php/empresarial/ article/view/53 
OLIVEIRA, M.A.; CARRÃO-PANIZZI, M.C.; MANDARINO, J.M.G.; LEITE, R.S.; CAMPOS FILHO, P.J.; VICENTINI, M.B. Quantificação dos teores de açúcares, oligossacarídeos e amido em genótipos/cultivares de soja (Glycine max (L) Merrill) especiais utilizados para alimentação humana. Brazilian Journal of Food Technology, v.13, n.1, p.23-29, 2010. https://www.alice.cnptia.embrapa.br/alice/bitstream/doc/856227/1/ QuantificacaodosteoresdeacucaresoligossacarideoseamidoemgenotiposcultivaresdesojaGlycineMaxLMerrilespeciaisutilizadosparaalimentacaohumana.pdf

PÁDUA, G.P.; ZITO, R.K.; ARANTES, N.E.; FRANÇA-NETO, J.B. Influência do tamanho da semente na qualidade fisiológica e na produtividade da cultura da soja. Revista Brasileira de Sementes, v.32, n.3, p.9-16, 2010. http://www.scielo.br/pdf/rbs/v32n3/v32n3a01.pdf

PINTO, T.L.F.; CICERO, S.M.; FRANÇA-NETO, J.B.; FORTI, V.A. An assessment of mechanical and stink bug damage in soybean seed using X-ray analysis test. Seed Science and Technology, v.37, n.1, p.110-120, 2009. https://ainfo.cnptia.embrapa.br/digital/bitstream/ item/113318/1/An-assessment-of-mechanical-and-stink-bugdamange-in-soybean-seed-using-X-ray-analysis-test.pdf
SILVA, M.A.D.; COELHO JÚNIOR, L.F.; SANTOS, A.P. Vigor de sementes de coentro (Coriandrum sativum L.) provenientes de sistemas orgânico e convencional. Revista Brasileira de Plantas Medicinais, v.14, p.192-196, 2012. http://www.scielo.br/pdf/rbpm/ v14nspe/12.pdf

TAVARES, L. C.; RUFINO, C. A.; BRUNES, A. P.; TUNES, L. M.; BARROS, A. C. S. A.; PESKE, S.T. Desempenho de sementes de soja sob deficiência hídrica: rendimento e qualidade fisiológica da geração F1. Ciência Rural, v. 43, n. 8, p. 1357-1363, 2013. http:// www.scielo.br/pdf/cr/v43n8/a22213cr2012-0950.pdf

VASCONCELOS, E.S.; REIS, M.S.; SEDIYAMA, T.; CRUZ, C.D. Análise não-paramétrica da sanidade de sementes e índices de eliminação e classificação de genótipos de soja. Pesquisa Agropecuária Brasileira, v.43, n.3, p.341-348, 2008. https://www. embrapa.br/busca-de-publicacoes/-/publicacao/124187/analise-naoparametrica-da-sanidade-de-sementes-e-indices-de-eliminacao-eclassificacao-de-genotipos-de-soja 